\section{Cause of blue petal colour}

SIR - The question of how blue flower colour develops is a fascinating problem which has long attracted attention ${ }^{1,2}$. Early this century Willstätter proposed the $\mathrm{pH}$ theory ${ }^{3}$, and soon after, Shibata and Shibata put forward their metal complex theory ${ }^{4}$ on the basis of the finding that the vacuolar $\mathrm{pH}\left(\mathrm{pH}_{\mathrm{v}}\right)$ in plant cells is generally around 5 , and more acidic than that of the cytosol ${ }^{5}$. We were earlier able to confirm the validity of the metal complex

at $\mathrm{pH} 6.40$ did not result in any bathochromic shift, suggesting no participation of metal complexation.

Light microscopy of transverse sections of petals confirmed that HBA was distributed homogeneously in the vacuoles of both types of epidermal cells, but not in the vacuoles of the parenchyma cells. For measuring $\mathrm{pH}_{\mathrm{v}}$ a cut petal was set on a Plexiglas vessel with its abaxial side uppermost and the tip of a double-barrelled $\mathrm{pH}$ microelectrode ${ }^{11}$ was inserted into the epidermal cells. The $\mathrm{pH}$ profile gained by gradually advancing the electrode tips exhibited three stable $\mathrm{pH}$ stages (Fig. 2). The $\mathrm{pH}$ value of the first inserted abaxial epidermal cell of a blue petal was higher than 7.5 and that of its redepidermis was around 6.6. After the first advancement (Fig. 2, first arrow), the $\mathrm{pH}$ suddenly decreased to around

Blue open flower
Purplish red bud Purple flower

$\left(\mathrm{CO}_{2}\right.$, treated)

Blue open flower Abaxial epidermis
Abaxial epidermis Abaxial epidermis

$7.7 \pm 0.2 *$

$6.6 \pm 0.4 * *, \#(22)$

$6.9 \pm 0.3 * *$, \# (7)

Purplish red bud

Parenchyma

$6.0 \pm 0.4 \#$

Data fluctuated within $\pm 0.1 \mathrm{pH}$ unit per min. Values are means $\pm s$. d. (no. of experiments). Significant differences $(P<0.001)$ were obtained between the $*$ and $* *$, and \# and \#\#.

theory for commelinin, the blue pigment of Commelina communis, by structural determination ${ }^{6}$. However, $\mathrm{pH}$ microspectrophotometric measurements, by Asen et al., of blue morning glory petals indicated an alkaline cell sap, which could be responsible for the blue flower colour ${ }^{7}$. Their methods were not able to assess $\mathrm{pH}_{\mathrm{v}}$ directly in living cells and therefore we have measured the $\mathrm{pH}_{\mathrm{v}}$ of individual blue and red coloured living cells, of morning glory using a proton selective microelectrode 8 .

The open flower of the morning glory, Ipomoea tricolor cv. heavenly blue, is light blue, although the buds are purplish red (Fig. 1a). We determined the structure of heavenly blue anthocyanin (HBA, Fig. 1b) ${ }^{9}$ and confirmed using HPLC that both red buds and blue open flowers contain only HBA as a pigment. In aqueous solutions of various $\mathrm{pH}$ the colour of this pigment varied widely with variation in $\mathrm{pH}^{1}$. The spectra of HBA in aqueous solutions at $\mathrm{pH}$ values of 7.68 and 6.37 corresponded to the reflective spectra of the open petal and the bud, respectively, and their colours were stabilized by intramolecular stacking of caffeic acid residues (sandwich-type tacking) ${ }^{1,10}$. Addition of $\mathrm{Al}^{3+}$ or $\mathrm{Fe}^{3+}$ ions to the HBA solution
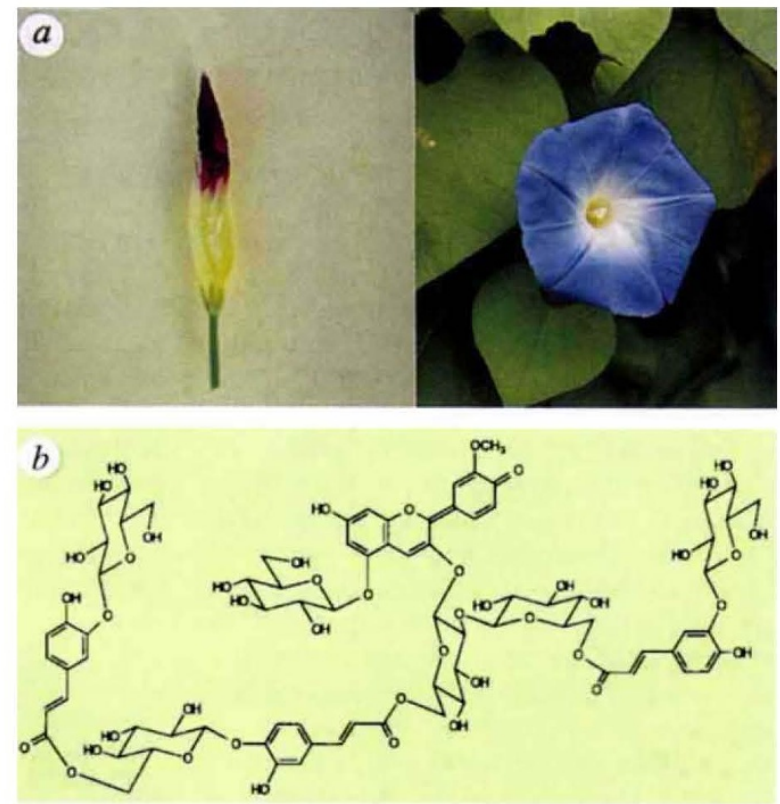

FIG. 1a, Blue blooming flower (right) and the bud (left) of Ipomoea tricolor $\mathrm{cv}$. heavenly blue. $b$, Structure of heavenly blue anthocyanin (HBA) ${ }^{9}$.

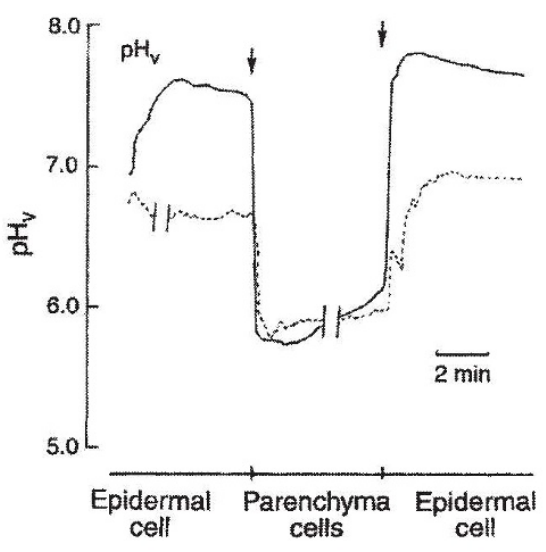

FIG. 2 Profiles of the vacuolar $\mathrm{pH}\left(\mathrm{pH}_{\mathrm{v}}\right)$ of blue open flower-petal (solid line) and red bud-petal (dotted lines) cells using double-barrelled $\mathrm{pH}$ sensitive microelectrodes ${ }^{11}$. The tip was inserted at an angle of $45^{\circ}$ into the cells under microscopic observation. A three-step change in $\mathrm{pH}$ values was observed when the tip was advanced stepwise. Arrows, advance of the electrode.

change correlated with the $\mathrm{pH}_{\mathrm{v}}$ just as in the in vitro case with isolated pigment.

The present study provides clear evidence that colour variation in the blue flower petals of Ipomoea tricolor cv. heavenly blue is caused by the unusually high vacuolar $\mathrm{pH}$. Independent of whether metal complexation ${ }^{5}$ or a high vacuolar $\mathrm{pH}$ is the causal stimulus, the mechanism of blue-colour development involves an anionic anhydrobase, the quinonoidal anion of anthocyanin ${ }^{2}$.

Kumi Yoshida

School of Life Studies,

Sugiyama

Jogakuen University,

Chikusa,

Nagoya 464, Japan

Tadao Kondo*

Chemical Instrument Center,

Nagoya University, Chikusa,

Nagoya 464-01, Japan

Yoshiji Okazaki

Department of Biology, Osaka Medical College, Takatsuki 569, Japan

\section{Kiyoshi Katou}

School of Informatics and Sciences,

Nagoya University,

Chikusa, Nagoya 464-01, Japan

* To whom correspondence should be addressed.

1. Goto, T. \& Kondo, T. Angew. Chem. Int. Engl. 30, 17-33 (1991).

2. Brouillard, R. \& Dangles, O. in The Flavonoids, Advances in Research Since 1988 (ed. Harborne, J. B. ) 565-588 (Chapman and Hall, London, 1994).

3. Willstätter, R. \& Everest, A. E. Justus Liebigs Ann. Chem. 401, 189-232 (1913).

4. Shibata, K., Shibata, Y. \& Kashiwagi, I. J. Am. Chem. Soc., 41, 208-220 (1919).

5. Kurkdjian, A. Guern, J. A. Rev. PI. Physiol. Pl. molec. Biol. 40, 271-303 (1989).

6. Kondo, T. et al. Nature, 358, 515-518 (1992).

7. Asen, S., Stewart, R. N. \& Norris, K. H. Phytochemistry 16, 1118-1119 (1977).

8. Felle, H. Bertl, A. J. exp. Bot. 37, 1416-1428 (1986).

9. Kondo, T., Kawai, T., Tamura, H. \& Goto, T. Tetrahedron Lett. 28, 2273-276 (1987).

10. Yoshida. K., Kondo, T. \& Goto, T. Tetrahedron 48, 4313-4326 (1992)

11. Okazaki, Y., Tazawa, M. Iwasaki, N. Plant Cell Physiol. 35, 943-950 (1994). 